\title{
Effects of Prenatal and Early Life Malnutrition: Evidence from the Greek Famine
}

\author{
Sven Neelsen \\ Thomas Stratmann
}

CESIFO WORKING PAPER NO. 2994

CATEGORY 5: ECONOMICS OF EDUCATION

MARCH 2010

An electronic version of the paper may be downloaded

- from the SSRN website:

- from the RePEc website:

- from the CESifo website:

www.SSRN.com

Www.RePEc.org

www.CESifo-group.org/wp 


\title{
Effects of Prenatal and Early Life Malnutrition: Evidence from the Greek Famine
}

\begin{abstract}
This paper examines the long run education and labor market effects from early-life exposure to the Greek 1941-42 famine. Given the short duration of the famine, we can separately identify the famine effects for cohorts exposed in utero, during infancy and at one year of age. We find that adverse outcomes due to the famine are largest for infants. Further, in our regression analysis we exploit the fact that the famine was more severe in urban than in rural areas. Consistent with our prediction, we find that urban-born cohorts show larger negative impacts on educational outcomes than the rural-born cohorts.
\end{abstract}

JEL-Code: I10, I12, I29, J13, J24.

Keywords: famine, health, regression discontinuity, Greece.

Sven Neelsen

Ifo Institute for Economic Research at the University of Munich

Poschingerstrasse 5

81679 Munich

Germany

neelsen@ifo.de
Thomas Stratmann

George Mason University

Department of Economics

4400 University Drive

Fairfax, VA 22030

USA

tstratma@gmu.edu

March 11th, 2010 


\section{Introduction}

Several hundred million children, most of which grow up in developing or middle-income countries, suffer from hunger (Victoria et al. 2008). Recent research suggests that such nutritional deprivation in childhood may have irreversible long term effects not only on health status but also educational and labor market performance. The adverse effects appear to be strongest for individuals that are exposed to undernourishment in utero or during the first two years of life (Bryce et al. 2008). Hoddinott et al. (2008) argue that because of hunger, more than 200 million of today's children will fail to reach their full development potential in the future.

Despite the recent growth in interest in the long-term consequences of early life undernourishment, causal evidence on the relationship remains scarce (Rasmussen 2001, Walker et al. 2007). Yet, ignoring that exposure to early life undernourishment is often not random can lead to biased estimates of the effects of malnourishment on health, education, and other outcomes.

To address this shortcoming, scholars have begun to examine the consequences of nation-wide famines which can be viewed as quasi experiments. The 1959-61 Chinese famine is the most prominent case (Luo et al. 2006, Chen and Zhou 2007, Almond et al. 2007, Gørgens et al. 2007, Meng and Qian 2009). While the Chinese famine studies are an important contribution to the literature, the three year duration of the Chinese famine makes it impossible to distinguish between the consequences of exposure in the second as opposed to the first year of life or in utero. For instance, it is impossible to quantify the effect of famine exposure in the first year of life for the Chinese 1961 birth cohort because this cohort not only experienced the famine during the first year of life but was already exposed in utero. Further, the long duration and severity of the Chinese famine had substantial impacts on both mortality and reproductive behavior which gives rise to concerns of selection bias (Song 
2009). For example, concern regarding selection arises if high mortality among individuals in the treatment group changes the characteristics of the survivors in the treatment group relative to the individuals in the comparison group which does not experience comparable mortality (Gørgens et al. 2007, Song 2009).

In this paper we study the long term effects of early life exposure to the Greek famine which started in the Fall of 1941 and lasted until early 1942. ${ }^{1,2}$ Examining the Greek famine offers several advantages. Relative to the Chinese famine, selection issues are less severe because the famine was rather short in duration (6-8 months) and compared to other famines, mortality among young children was relatively low. Therefore, in comparison to other famines the Greek cohorts with famine exposure are likely similar to Greek cohorts without famine exposure. Moreover, the short duration of the famine allows us to distinguish the effects of undernourishment at specific ages, that is, during the second year of life, the first year of life, and in utero. In the following we refer to those exposed in the second year of life as one year olds, to those exposed in the first year of life as infants, and to those exposed in utero as fetuses. Another advantage of studying the effects of the Greek famine on long term outcomes is that the Greek famine does not coincide with epidemics of infectious disease for which long-run outcomes might work quite differently than for undernourishment (Hionidou 2006).

We find that undernourishment of one year olds, infants and fetuses impairs the development of human capital in the long run. Being exposed to famine at young age lowers the likelihood of being literate, the likelihood of upper secondary schooling and the number of years of education. The effects are largest for the cohorts exposed as infants followed by

\footnotetext{
${ }^{1}$ The Greek famine has received little attention in the famine and other academic literatures. Further, there is "a complete absence of reference to the food crisis of the occupation years in the collective memory of the Greek population, no collective of even official memory of the famine, let alone collective trauma such as that relating to the Irish famine.”(Hionidou 2006, p.30-31)

2 Valaoras' (1946) analysis of short-term somatometric impacts (height, weight, weight-for-height) for a small sample of Athens-born famine exposed children forms the exception to an absence of quantitative studies.
} 
the cohort exposed as one year olds. Relative to these two cohorts we find only small effects for the cohort exposed as fetuses.

In the next section, we review earlier work on the nexus between early life health shocks and later-life health and socioeconomic outcomes. In Section 3 we provide a description of the Greek 1941/42 famine. We describe our empirical strategy in Section 4. Section 5 contains results and Section 6 concludes.

\section{Early Life Undernourishment and Later Life Outcomes}

Barker's fetal origins hypothesis suggests a causal relationship between health in utero and later in life (e.g. Barker 1998). Empirical tests of this hypothesis have typically used birth weight as a proxy for in utero development The results from these tests indicate a strong negative association between birth weight and the risk of chronic disease in adults, especially after the primary reproductive age. It is suspected that in order to increase the chance of survival in the face of fetal undernourishment, blood and nutrients are diverted to the brain rather than other vital organs. The development of these organs then would either be impaired or permanently adapted to the nutritional deprivation, creating so called thrifty phenotypes (Hales and Barker 1992, Barker and Hanson 2004). Under improved nutritional conditions later in life, thrifty phenotype individuals would face a higher chance of metabolic disorders such as type-II diabetes (Hales 1997). ${ }^{3}$

Further, in utero malnutrition impairs cardiac health (Hoet and Hanson 1999) and kidney functioning (Brenner and Chertow 1994). Moreover, Walker et al. (2007) present evidence that low birth weight babies have inferior cognitive skills, problem solving abilities, developmental levels, and are less active, happy, cooperative, and more inhibited. Studies by Case et al. (2002) and Almond (2006) show that the negative long-run effects of impaired

\footnotetext{
${ }^{3}$ According to Stocker et al. (2005) the relative lack of metabolic disorders in African countries is caused by the fact that poor in utero nutrition is typically followed by nutritional scarcity after birth.
} 
fetal development do not stop at health, but translate into lesser educational attainment, employment opportunities and income. Twin studies that control for unobserved factors like genetic endowments as confounding factors find support for the negative correlation of birth weight and educational and labor market performance (Behrman and Rosenzweig 2004, Almond et al. 2005, Oreopoulos et al. 2008, Black et al. 2007).

Individuals that experience severe undernourishment in their early childhood as opposed to in utero also experience negative long-term health outcomes. In their review of medical evidence from Asian, African, and South American developing countries, Walker et al. (2007) and Victoria et al. (2008) show that similar to undernourished fetuses, undernourishment of children in the first 24 months of life is associated with reduced adult height, higher blood glucose concentrations, increased blood pressure, harmful lipid profiles, deficits in cognitive skills and an increased chance of mental illness. Just as for malnourished fetuses, the negative effects from exposure to severe undernourishment at early childhood translate into disadvantageous socioeconomic outcomes, like lower educational attainment and reduced labor income.

To address the possibility that early life nutritional levels may not be exogenous, scholars have recently begun to examine famines. Investigating long run effects on cohorts born shortly around or during episodes of severe nutritional deprivation, these studies have produced mixed evidence in terms of long run effects.

St. Clair et al. (2005) find that in utero exposure to the Chinese famine of 1959-61 is associated with higher levels of adult schizophrenia. For the same famine Luo et al. (2006) find that in utero exposure is associated with increased rates of obesity among women, and Meng and Qian (2009) suggest that in utero exposure results in negative effects on height, but no impact on coronary or metabolic conditions. Almond (2007) provides evidence that 
Chinese men exposed to the famine in utero are less likely to be literate, to work, and to be married than surrounding cohorts.

Stanner et al. (1997) and Stanner and Yudkin (2001) examine the consequences of the German siege of Leningrad (1941-44) which led to severe starvation of the city’s inhabitants. They find that in utero exposure had no effect on metabolic or cardiac conditions later in life. Finally, the results by Kannisto et al. (1997) suggest no impact on longevity among cohorts conceived during or shortly before the Finnish famine of 1866-68 that killed up to 8 percent of the country's population. Because of the length and severity of the Leningrad and Finnish famines, the absence of health effects among individuals with in utero exposure could be driven by positive selection into fertility and survival during and after nutritional crises. If survivors exposed early in life have better genetic endowments than surrounding cohorts, this would upward bias any estimates of negative famine effects.

The scope for positive selection was smaller in the Dutch famine of 1944-45 in which nutritional crisis was caused by a six month Nazi blockade of the western Netherlands. In a series of papers, Roseboom et al. (e.g. 1999, 2000a, 2000b, 2001) present evidence that in utero famine exposure is associated with impairments of the central nervous system, worse self-reported health, and coronary heart disease. Neugebauer et al. (1999) find a higher prevalence of antisocial personality disorder during adulthood, and the results by Ravelli et al. $(1998,1999)$ propose increased glucose resistance later in life and higher rates of obesity in cohorts exposed during the fetal stage. However, the unique dataset that was collected to investigate the long-run health effects of prenatal exposure to the Dutch famine does not contain socioeconomic outcome measures like educational attainment or labor market performance.

In contrast to the fetal origins hypothesis, studies that investigate the long-run effects of postnatal malnutrition are, to the best of our knowledge, limited to the 1959-61 Chinese 
famine. Meng and Qian (2009), Chen and Zhou (2007) and Gørgens et al. (2007) here find negative effects for children exposed to the Chinese famine for height, weight, weight-forheight, education and labor supply, income and housing space for survivors that experienced the famine during early childhood.

\section{The Greek 1941/1942 Famine}

On April 30th 1941, only twenty-four days after Nazi Germany had joined the invasion of Greece by Italian forces, open warfare ended with the Greeks’ unconditional surrender and the country’s occupation by German, Italian, and Bulgarian troops. ${ }^{4}$ The Allied forces responded with a full naval blockade, cutting off all imports to Greece, including foods. Immediately following victory, the occupying forces divided the country into 13 zones between which any movement of goods and people was strictly prohibited. Also within the zones, the confiscation of fuels and all means of transportation including fishing boats and pack animals reduced mobility to a minimum. The occupiers seized strategic industries, and appropriated or bought all stocks of commodities like tobacco, olive oil, cotton, and leather and transferred them to their home countries.

The occupying forces ordered a newly installed central government to reorganize the food supply to the Greek civil population. Farmers had to pay a 10 percent in kind tax on their produce and sell to the government at fixed prices all production above the subsistence level. Moreover, the food price controls and rationing that had been in place before the Greek defeat were now tightened. With the low government prices and newly imposed taxes, farmers went to great length to hide their produce from the officials and traders pulled their merchandise from the shelves. The naval blockade and warfare in surrounding countries in

\footnotetext{
${ }^{4}$ Hionidou (2006) provides a detailed account of the famine from a socio-historic perspective and Mazower (1993) focuses on the political and military implications of the 1941-44 occupation period.
} 
addition severed the foreign trade routes on which Greece traditionally depended for food imports.

The nutritional situation became critical in the summer of 1941 and in the fall turned into a full-blown famine. In the Greater Athens area, the calorific value of rations and food provided by public or charity soup kitchens deteriorated from 600 calories per day and person in July of 1941 to 320 in November of 1941. In many places, civil registration records were discontinued during the occupation (Valaoras 1960). Where they were not, the data suggest mortality increases between 300 and 1000 percent compared to pre-war years. Estimates of a country-wide death toll of the famine vary between 100,000 and 200,000 (Hionidou 2006) or 1.4 to 2.8 percent of the population, the large majority of which occurred between October 1941 and March 1942 (Helger 1949). ${ }^{5}$

Not all parts of Greece experienced equal levels of food scarcity. While comprehensive data on regional famine severity does not exist, the available evidence indicates that with the severe movement restrictions, proximity to agricultural production and the level of urbanization became crucial determinants of famine mortality. Hionidou (2006) estimates that the mortality increases in urban areas were on average twice as large as in the countryside. Hence, while certain isolated islands and mountain villages also suffered high losses during the famine, the urban populations took the brunt of the death toll.

Because of the efforts of the Greek Diasporas in the US and Britain, the situation of the Greek civilian population soon became a public issue in the Allied countries. The increasing public pressure eventually led to the lifting of the naval blockade in February 1942. Wheat shipments soon began and together with the rising temperatures of springtime, this brought down mortality rates. The international relief focused mainly on children. In the

\footnotetext{
${ }^{5}$ For the May 1941 to April 1943 period, estimates of excess deaths range up to 6.1 percent of the population (250.000-400.000 deaths). However, these figures also include many victims of civil warfare and the malaria outbreaks that occurred in some parts of the country after the famine in the summer of 1942 (Hionidou 2006).
} 
capital, the Red Cross in February started to provide daily milk rations ${ }^{6}$, medical services and clothing to children younger than two years. From March 1942 onwards, pregnant women and breastfeeding mothers received extra supplies which were further increased for women that were temporarily unable to breastfeed because of undernourishment.

Also in March 1942, the occupiers and Allied forces agreed to the establishment of the Swedish-run Joint Relief Commission to reorganize the public food supply system. The occupiers moreover committed to replace all appropriated agricultural produce with food imports of equal calorific value ${ }^{7}$ and relaxed the harshest mobility restrictions and price regulations. As a result, fresh produce from the June harvest and foodstuffs that had hitherto been hoarded entered the markets. Meanwhile, food shipments further grew in volume. Towards the end of 1942, the nutritional situation had returned to acceptable levels in most parts of the country (Hionidou 2006). ${ }^{8}$

\section{Data and Methods}

Our data come from the Greek National Population Housing Census from the IPUMS website (Minnesota Population Center 2009). These are individual level data from the 1971, 1981, 1991, and 2001 Greek Census waves. Each wave represents a 10 percent sample of the Greek population. In our regressions, we include the 11 cohorts born between 1936 and 1946 . The 1971 census sample therefore includes individuals between 25 and 36 years.

Correspondingly, the 1981 sample consists of individuals between 35 and 46 years, the 1991 sample of individuals between 45 and 56 years and the 2001 sample of individuals between 55 and 66 years.

\footnotetext{
${ }^{6}$ The form in which milk rations were provided required immediate consumption. This method improved hygiene in the preparation of the rations and assured that the milk actually reached the small children instead of being bartered for other goods (Helger 1949).

${ }^{7}$ According to sources cited by Hionidou (2006) this agreement was mostly adhered to.

${ }^{8}$ Where mortality remained elevated beyond mid 1942, this was in most cases not primarily due to acute food scarcity but rather outbreaks of malaria, partisan warfare and retaliation and also the beginnings of the Greek 1946-49 civil war (Hionidou 2006).
} 
As elaborated above, the medical literature proposes that early life undernourishment has particularly strong long run effects when experienced in the first 24 months of life or in utero. Therefore our treatment group consists of the 1940 birth cohort of which the majority was one year old when the famine struck, the 1941 birth cohort the majority of which experienced the famine during the infancy and the 1942 birth cohort where the majority experienced the famine as fetuses. ${ }^{9}$ In comparison, the cohorts born before 1940 had a much lower chance of being exposed to severe malnutrition in the first 24 month of life or in utero. Because the harshest phase of the famine was over in early 1942, the cohorts born in 1943 or later were not treated.

The treated 1940, 1941 and 1942 cohorts were between 29 and 31 in the 1971 sample, between 39 and 41 in the 1981 sample, between 49 and 51 in the 1991 sample and between 59 and 61 in the 2001 sample.

The regression discontinuity approach we apply exploits the discontinuous change in treatment probability to produce estimates of the mean treatment effects on the cohort level. We use individual data from the Greek census’ $1936-1946$ birth cohorts $^{10}$ to estimate by OLS

$$
y_{i t}=\mathrm{cons}+\beta_{1} 1940+\beta_{2} 1941+\beta_{3} 1942+\operatorname{sex}_{i t}+y o b_{i t}+y o b_{i t}{ }^{2}+\varepsilon_{i t} \quad .
$$

Here $y_{i t}$ represents a set of educational outcomes and a measure of job prestige for person $i$ in year $t .1940,1941$ and 1942 are indicators that equal 1 if the individual is born in the respective year and 0 otherwise. The variable sex is a gender dummy, and yob denotes the year of birth thereby controlling for linear trends in the outcome variables $y$. Moreover, to

\footnotetext{
${ }^{9}$ The Greek census does not contain month of birth information. With the 1940-42 birth cohorts we therefore consider as our treatment group those who experienced the most severe episode of nutritional deprivation (October 1941 - March 1942) in utero or up to their $27^{\text {th }}$ month of life. Specifically, the oldest members of the 1940 birth cohort (born in January) were exposed during the $22^{\text {nd }}$ and $27^{\text {th }}$ and the youngest (born in December) during the $11^{\text {th }}$ and $16^{\text {th }}$ month of life. Accordingly, the 1941 cohort received treatment between the $10^{\text {th }}$ and $15^{\text {th }}$ month of life (born in January) and the last three month of gestation up to the $4^{\text {th }}$ month after birth (born in December). Finally, for the 1942 birth cohort, those born in January experienced the famine during the 4 last month of the gestation period and the first three months after birth. Those born later than March 1942, i.e. the majority of the cohort, were exposed to undernourishment only in utero.

${ }^{10}$ The large number of observations in the Greek censuses permits us to use a rather short 11 cohort sample. By using this 11 cohort sample we seek to increase homogeneity in unobserved factors across birth cohorts and thus limit the scope for sample selection.
} 
account for non-linearities in the outcome trends we include the squared year of birth $y o b^{2}$ (Almond and Mazumder 2005).

In this model the coefficients $\beta_{1}, \beta_{2}$ and $\beta_{3}$ represent the departures of the 1940-42 birth cohorts from a secular outcome trend over the 1936-46 cohorts. Because the Greek winter famine lasted only 6-8 months, $\beta_{1}, \beta_{2}$ and $\beta_{3}$ can be interpreted as the mean effects of undernourishment experienced exclusively at a specific age rather than over a longer period of time. In our specification, $\beta_{1}$ represents the departure in outcomes for the 1940 birth cohort exposed to the famine at age one.. Accordingly $\beta_{2}$ is the departure in outcomes for those born in 1941, that is, those exposed during infancy, and $\beta_{3}$ is the departure in outcomes for those born in 1942 and thus exposed as fetuses.

One of our outcome variables is whether a person is literate. ${ }^{11}$ Further, the Greek census reports the highest level of education achieved. From this measure we construct a variable which equals one if an individual has completed upper secondary or technical school and 0 otherwise. ${ }^{12}$ Further, using the regular time required to gain the reported highest educational attainment we construct a years of education variable. ${ }^{13}$ To construct this variable, we use an approximation that is based on the Greek educational system (European Commission 2009). ${ }^{14}$

Finally, while the census does not have data on income or wages, it contains detailed information on occupation. The more than 400 occupational categories in the Greek census are in many cases equal to those of the 4-digit ISCO88 scheme. ISCO88 occupations can be

\footnotetext{
${ }^{11}$ The method to determine literacy status is not the same across the 1971-2001 census waves. While the 1971 census obtained literacy status through direct questioning, the 1981-2001 waves do not contain such a question but instead consider individuals literate if they ever attended school.

${ }^{12}$ In Greece, compulsory schooling comprises six years of primary school and three years of lower secondary education (gymnasium). The additional three years of upper secondary schooling (lyceum) are optional and comparable to the last two or three years of American High School education.

${ }^{13}$ There are differences across samples in the level of detail for the highest degree achieved: the 1971 and the 1981 Census combines all post-secondary degrees into one category and differentiates only between university and other post-secondary degrees. By contrast, the 1991 and 2001 samples have considerably more detail among higher degrees, but only the 2001 sample is the only one that identifies persons with a doctoral degree. As a result, while our years of education measure is not necessarily comparable across censuses.

${ }^{14}$ The STATA-code used for variable transformation can be obtained on request.
} 
converted into scores in Ganzeboom et al.'s (1992) International Socio-Economic Index of Occupational Status (ISEI). The index assigns each occupation a prestige score that lies between 16 for the least prestigious and 90 for the most prestigious occupations. Our conversion follows that by Ganzeboom and Treiman (1996). For the occupational categories in the Greek census that did not precisely match the 4-digit ISCO88 codes we applied the ISEI conversions for the more aggregated 3-digit or 2-digit ISCO88 categories. $^{15}$

We assume that the error term $\varepsilon$ is uncorrelated with the independent variables in our model including the 1940-42 birth cohort dummies. This assumption requires that the unobserved characteristics captured in $\varepsilon$ are equally distributed across the 1936-46 birth cohorts, that is, that selection into the treatment group is random with regards to $\varepsilon$. If this assumption holds, outcome changes that remain after controlling for secular trends are attributable to the discontinuous changes in treatment probability.

However, the randomness assumption may not be satisfied. The circumstances of the Greek famine suggest some positive selection into the treatment group. The selection likely operated through both mortality and fertility.

With respect to famine mortality, we suspect that individuals with adverse genetic endowments had a lesser chance of survival if born 1940-42 than individuals in our control groups. Our control groups consist of the 1936-39 cohorts that suffered lower mortality than those in our treatment cohorts (Valaoras 1946) and the 1943-46 cohorts that had no direct exposure to the famine at all. If a culling of the weakest did in fact occur and if genetic endowment is correlated with educational and labor market performance, our estimates $\beta_{1}, \beta_{2}$ and $\beta_{3}$ will understate the true effect of early-life famine exposure. The same logic applies to

\footnotetext{
${ }^{15}$ The STATA-code for conversion to the ISEI scores can be obtained from the authors on request. Because the 2001 census used a different job classification method than the prior census waves, estimates of ISEI-scoreeffects are not comparable across the 2001 and 1971-1991 censuses.
} 
social background as the famine claimed most of its victims among the poor (Hionidou 1946). In light of these selection issues our estimates identify a lower bound.

With respect to fertility, positive selection is largest for the cohort conceived during the 1942 famine. This is because unlike for the prior cohorts, for the 1942 cohort positive selection did not only occur though mortality but also though fertility. For instance, Valaoras (1946) estimates that during the winter-famine up to seventy percent of females in the Greater Athens area stopped menstruating because of severe undernourishment (famine amenorrhea). Further, lost births were more frequent among the poor and this reduced the share of individuals with poor parents. If having poor parents is associated with inferior outcomes later in life, the selective fertility reductions gives the 1942 cohort better outcomes than the comparison groups. This would in turn cause downward bias in our estimates.

However, the possible bias in our basic specification (1) may not be unambiguously downward. If, for instance, famine mortality was low in places with poor educational and labor market opportunities, survivors from these places may be overrepresented in the treated 1940-42 cohorts. In this case the place of birth is an important control variable since it is correlated with famine intensity and survivorship. Specifications that do not account for birthplaces would therefore have an upward bias. Because the 2001 census includes detailed birthplace information our data allow us to address this selection issue for the 2001 census wave.

The scope for selection is larger and thus comparability between treatment and control groups more limited in more severe and extended famines. The degree of bias from sample selection upon unobserved determinants of educational and labor market performance for our sample is likely lower than for other famines. For example, while the Greek famine lasted only 6-8 months and claimed 1.4-2.8 percent of the population (Hionidou 2006) the siege of 
Leningrad lasted almost three years and killed as much as one third of the city's inhabitants (Stanner et al. 1997).

\section{Results}

Table 1 provides descriptive statistics for Greek citizens in the 1971, 1981, 1991, and 2001

Greek censuses. It compares variable means for the 1940-42 cohorts to those of the surrounding 1939 and 1943 cohorts. The table shows that with respect to literacy rates we do not observe large differences between the 1940-42 birth years and the adjacent cohorts. However, across all census waves the treated cohorts (1940-42 birth years) on average are about 2 percentage points less likely to have completed upper secondary or technical school. Further, individuals born 1940-42 have on average had between 1.4 and 2.4 months less education than individuals born in the surrounding years. In terms of labor market outcomes, Table 1 shows that famine exposure early in life is associated with less job prestige.

Across all census waves the share of females is higher among the treated than among the non-treated cohorts, with the difference ranging between 0.2 and 1.8 percentage points. The differences likely reflect the higher likelihood of male children succumbing to the famine as reported for both the Greek and other famine episodes (Helger 1949, Jakobovits 1991). Finally, the share of individuals born in urban areas is two percentage points lower in the cohorts with early life famine exposure as opposed to surrounding cohorts, likely reflecting the reported differences in famine severity between urban and rural areas (Helger 1949).

Table 2 shows the coefficient estimates for our basic model. We estimate for the sample of Greek citizens in each of the four 1971-01 census waves.

For the 1940 cohort of individuals treated as one year olds we find a reduction of about half a percentage point in literacy in the 1981 and 1991 censuses. For this cohort, the reductions in the chance to complete upper secondary or technical school range between 1.3 
Table 1: Variable means over 1940-42 and the two surrounding birth cohorts

\begin{tabular}{|c|c|c|c|c|c|c|c|c|}
\hline \multirow[b]{2}{*}{ Cohorts } & \multicolumn{2}{|c|}{1971} & \multicolumn{2}{|c|}{1981} & \multicolumn{2}{|c|}{1991} & \multicolumn{2}{|c|}{2001} \\
\hline & $1940-42$ & surrounding & $1940-42$ & surrounding & $1940-42$ & surrounding & $1940-42$ & surrounding \\
\hline Literate & .950 & .950 & .958 & .962 & .953 & .954 & .961 & .961 \\
\hline SE & {$[.2187]$} & {$[.2188]$} & [.1999] & [.1910] & [.2108] & [.2089] & [.1943] & [.1928] \\
\hline $\mathrm{N}$ & 29,419 & 19,616 & 33,114 & 21,134 & 32,998 & 20,850 & 32,059 & 20,467 \\
\hline Upper secondary education & .218 & .237 & .233 & .253 & .255 & .273 & .263 & .285 \\
\hline SE & {$[.4130]$} & {$[.4251]$} & [.4225] & {$[.4346]$} & [.4360] & {$[.4453]$} & {$[.4403]$} & {$[.4516]$} \\
\hline $\mathrm{N}$ & 28,999 & 19,342 & 33,114 & 21,134 & 32,998 & 20,850 & 32,059 & 20,467 \\
\hline Years in education & 7.244 & 7.380 & 7.405 & 7.616 & 7.697 & 7.838 & 7.735 & 7.919 \\
\hline SE & [3.6544] & [3.7200] & [4.0400] & [4.1263] & [4.2462] & [4.3216] & [4.3239] & [4.4438] \\
\hline $\mathrm{N}$ & 28,999 & 19,342 & 33,114 & 21,134 & 32,998 & 20,850 & 32,059 & 20,467 \\
\hline ISEI-score & 34.501 & 34.763 & 36.895 & 37.430 & 37.170 & 37.242 & 36.454 & 37.637 \\
\hline SE & [14.6460] & [14.5238] & [15.5255] & [15.8238] & [16.2096] & [16.3432] & [16.7032] & [17.2310] \\
\hline $\mathrm{N}$ & 17,314 & 11,542 & 20,431 & 13,467 & 18,979 & 11,940 & 10,812 & 6,647 \\
\hline Sex & .521 & .519 & .515 & .497 & .507 & .499 & .527 & .517 \\
\hline SE & [.4996] & [.4997] & [.4998] & {$[.5000]$} & [.5000] & {$[.5000]$} & [.4993] & [.4997] \\
\hline $\mathrm{N}$ & 29,452 & 19,630 & 33,114 & 21,134 & 33,009 & 20,857 & 32,059 & 20,467 \\
\hline Urban born & & & & & & & .296 & .315 \\
\hline SE & & & & & & & [.4567] & [.4647] \\
\hline $\mathrm{N}$ & & & & & & & 31,299 & 19,935 \\
\hline
\end{tabular}

Our samples form subsamples of the 1971-01 Greek censuses in that we only include Greek citizens in our calculations.

The surrounding cohorts are 1939 (famine exposure in the third year of life) and 1943 (no direct famine exposure).

Standard errors are reported in brackets. 
Table 2: OLS estimates of departures from 1936-46 cohort trend for the 1971, 1981, 1991 and 2001 censuses

\begin{tabular}{|c|c|c|c|c|c|c|c|c|c|}
\hline & \multirow[b]{2}{*}{ Cohort (exposed in) } & \multicolumn{2}{|c|}{ (1) 1971 census } & \multicolumn{2}{|c|}{ (2) 1981 census } & \multicolumn{2}{|c|}{ (3) 1991 census } & \multicolumn{2}{|c|}{ (4) 2001 census } \\
\hline & & Coefficient & $\mathrm{SE}$ & Coefficient & SE & Coefficient & SE & Coefficient & SE \\
\hline \multirow[t]{3}{*}{ Literate } & 1940 (one year old) & -.002 & [.0022] & $-.006 * *$ & {$[.0028]$} & $-.005^{* *}$ & {$[.0026]$} & .000 & {$[.0024]$} \\
\hline & 1941 (infant) & $-.004 *$ & {$[.0025]$} & $-.011 * * *$ & {$[.0031]$} & $-.007 * *$ & [.0029] & $-.007 * * *$ & [.0027] \\
\hline & 1942 (fetus) & .001 & [.0022] & -.003 & [.0027] & -.001 & {$[.0026]$} & .002 & [.0023] \\
\hline $\mathrm{N}$ & & 119,368 & & 130,321 & & 129,372 & & 126,214 & \\
\hline \multirow[t]{3}{*}{ Upper secondary education } & 1940 (one year old) & $-.016 * * *$ & {$[.0045]$} & $-.013 * * *$ & {$[.0043]$} & $-.013 * * *$ & [.0039] & $-.018 * * *$ & [.0042] \\
\hline & 1941 (infant) & $-.022 * * *$ & {$[.0051]$} & $-.024 * * *$ & {$[.0050]$} & $-.018 * * *$ & [.0047] & $-.023 * * *$ & [.0049] \\
\hline & 1942 (fetus) & $-.026 * * *$ & {$[.0050]$} & $-.023 * * *$ & [.0049] & $-.021 * * *$ & [.0047] & $-.023 * * *$ & {$[.0048]$} \\
\hline $\mathrm{N}$ & & 117,638 & & 130,321 & & 129,372 & & 126,214 & \\
\hline \multirow[t]{3}{*}{ Years in education } & 1940 (one year old) & $-.147 * * *$ & {$[.0375]$} & $-.177 * * *$ & {$[.0482]$} & $-.159 * * *$ & [.0458] & $-.148 * * *$ & [.0434] \\
\hline & 1941 (infant) & $-.215 * * *$ & {$[.0431]$} & $-.293 * * *$ & {$[.0550]$} & $-.173^{* * *}$ & [.0534] & $-.235 * * *$ & {$[.0500]$} \\
\hline & 1942 (fetus) & $-.181 * * *$ & [.0414] & $-.200 * * *$ & {$[.0524]$} & $-.157 * * *$ & [.0513] & $-.173 * * *$ & [.0481] \\
\hline $\mathrm{N}$ & & 117,638 & & 130,321 & & 129,372 & & 126,214 & \\
\hline \multirow[t]{3}{*}{ ISEI-score } & 1940 (one year old) & $-.503^{* *}$ & {$[.2151]$} & $-.700 * * *$ & [.2117] & -.296 & [.2292] & -.456 & [.3328] \\
\hline & 1941 (infant) & $-.521 * *$ & {$[.2421]$} & $-.533 * *$ & [.2458] & -.235 & [.2632] & $-.839 * *$ & [.3487] \\
\hline & 1942 (fetus) & $-.478 * *$ & [.2356] & $-.583 * *$ & [.2419] & -.279 & [.2537] & $-1.111^{* * *}$ & [.3245] \\
\hline $\mathrm{N}$ & & 69,998 & & 80,993 & & 73,852 & & 43,177 & \\
\hline
\end{tabular}

In addition to the indicators for whether born in 1940, 1941, or 1942, all specifications include year of birth, year of birth squared and a sex indicator. Huber-White robust standard errors are reported in brackets. The table reports only point estimates and standard errors for the 1940, 1941 and 1942 indicators. 
in the 1981 and 1991 censuses and 1.8 percentage points in 2001. Time in education is also reduced for one year olds and the reductions are between 1.2 and 1.4 months in all four censuses. ${ }^{16}$ Finally, the ISEI occupational prestige score is 0.5 points below the trend for one year olds in the 1971 census and 0.7 points in the 1981 census. The ISEI reductions in the 1991 and 2001 are not statistically significant. ${ }^{17}$

The 1941 birth cohort exposed during infancy appears to be the most affected by the famine. It is the only cohort that shows significant reductions in the share of literate individuals over all census waves, ranging from 0.4 percentage points in 1971 to 1.1 percentage points in $1981 .^{18}$ The negative effect on the likelihood to complete upper secondary or technical school is statistically significant and ranges between 1.8 percentage points in 1991 and 2.4 percentage points in 1981. A similar picture emerges for years of education where being born in 1941 causes a reduction between 1.4 and 2.4 months in 1991 and 1981 respectively. We also find reductions in the ISEI score that are statistically significant in the 1971, 1981 and 2001 census waves where they range between 0.5 and 0.8 points.

In contrast to one year olds and infants, the 1942 cohort treated as fetuses does not display significant reductions in literacy. Instead, in two of the four censuses, the point estimates have positive signs. This possibly reflects the larger degree of sample selection we presume for individuals conceived during the famine. We do however find statistically significant reductions in the likelihood of completing upper secondary or technical school in all censuses that range between 2.1 percentage points in the 1991 census and 2.6 percentage

\footnotetext{
${ }^{16}$ Over time comparisons of the coefficient estimates for the years-of-education-variable need to take into account that the educational attainment variable that underlies our years-of-education-variable becomes more detailed with each census wave. However, when we use a harmonized years-of-education variable instead, we observe only minimal difference on the estimates' size. Results for this harmonized years-of-education-variable are available from the authors on request.

${ }^{17}$ Because the 2001 census used a different methodology for occupation coding, the magnitudes of the ISEIscore effects are not fully comparable between the 1971-91 and the 2001 waves.

${ }^{18}$ The doubling of the negative impact between the 1971 and 1981 census waves may in part be caused by the methodological differences in creating the literacy variable that we discuss in Section 4.
} 
points in the 1971. The total number of years in education is also lower for fetuses in all censuses and the reductions range between 1.3 and 1.7 months. With respect to the ISEIscore we find statistically significant reductions in the 1971, 1981 and 2001 censuses. The magnitude of these effects lies between 0.5 points in the 1981 and 1991 waves and 1.1 points in the 2001.

Summarizing, the results in Table 2, we find support for the hypothesis that early life exposure to famine worsens long term outcomes. We find statically significant negative effects on education, measured either as literacy, upper secondary education, or years of education for one or more of the treated cohorts across all census waves. When comparing the magnitudes of effects between the treated cohorts, we find that with respect to education, the adverse effects are largest for infants. For fetuses, the negative effect on upper secondary schooling is similar to that for infants while the reductions in years in education are a little smaller. As we noted before, because the majority of the cohort with fetal exposure was conceived during the famine it likely experienced positive selection through fertility in addition to selection through mortality. We therefore suspect a larger downward bias for fetuses as opposed to infants and one year olds. This consideration implies that our results do not necessarily suggest that fetal exposure to famine has less severe consequences for later life outcomes than exposure during infancy.

One concern regarding the estimates in Table 2 is that they might be biased because of a correlation between regional differences in famine intensity and unmeasured or unobservable characteristics that determine educational and labor market outcomes. No comprehensive data on regional famine intensity exists but contemporary reports indicate that the intensity reduced with the proximity to agricultural production (Helger 1946, Hionidou 
2006). This anecdotal evidence is supported in our data. ${ }^{19}$ We hence suspect that for children born between 1940 and 1942 the likelihood of survival was higher in rural areas and that rural born individuals may therefore be overrepresented in these cohorts. Thus, if being born in rural areas correlates with inferior educational and labor market opportunities then the estimates in Table 2 contain an upward bias. ${ }^{20}$

It is not clear whether the downward bias that we suspect because of positive genetic selection into survival is larger than any upward bias due to rural born individuals being overrepresented in the 1940-42 cohorts. As a result, we cannot determine whether the coefficients in our basic model in Table 2 over- or underestimate the true famine effects. However, because the 2001 census contains detailed birthplace information we can control for birthplace and therefore net out the upward bias from positive birthplace selection in the 2001 sample. The estimates from these alternative specifications will therefore identify a lower bound of the true famine effects.

Table 3 presents results based on the 2001 data. Again we use the sample of individuals born in Greece. The first column of Table 3 replicates the basic specification (1) for the Greece-born sample. Column 2 adds 53 dummy variables for the prefecture of birth. ${ }^{21}$ By including the dummies we control for all determinants of education and labor market outcomes that are specific to the prefecture of birth and constant over time. In column 3 we add an indicator for whether a person was born in an urban area and interaction terms between the urban birthplace and prefecture of birth dummies. Because of these interaction terms, this last specification not only controls for time-invariant prefecture and urban

\footnotetext{
${ }^{19}$ When we regress the urban birthplace indicator on the explanatory variables in model (1) we find that the likelihood of being born urban is significantly reduced by 0.9 percentage points for the 1940 cohort, 2.2 percentage points for the 1941 cohort and 4.4 percentage points for the 1942 cohorts.

${ }^{20}$ The correlation of birthplace and educational and labor market outcomes may for example be driven by structural differences in access to early life healthcare or parental education.

${ }^{21}$ In 2005, the average prefecture had a population of about 200,000, ranging from the most populous Athens prefecture with almost 2,700,000 million people to 23,000 in the Lefkada prefecture. Our results are robust to the inclusion of 156 indicators that break the birthplace information down below the prefecture level.
} 
Table 3: OLS estimates of departures from 1936-46 cohort trend with birthplace controls for the 2001 census

\begin{tabular}{|c|c|c|c|c|c|c|}
\hline \multirow[b]{2}{*}{ Cohort (exposed in) } & \multicolumn{2}{|c|}{ (1) Basic } & \multicolumn{2}{|c|}{ (2) Prefecture FE } & \multicolumn{2}{|c|}{ (3) Prefecture \& Urban FE } \\
\hline & Coefficient & SE & Coefficient & SE & Coefficient & SE \\
\hline Literate 1940 (one year old) & -.001 & {$[.0027]$} & .000 & {$[.0019]$} & -.001 & [.0018] \\
\hline 1941 (infant) & $-.007 * *$ & {$[.0030]$} & $-.007 * * *$ & [.0024] & $-.007 * * *$ & [.0023] \\
\hline 1942 (fetus) & .002 & {$[.0027]$} & .004 & [.0024] & $.004 *$ & [.0023] \\
\hline $\mathrm{N}$ & 123,793 & & 123,793 & & 123,793 & \\
\hline Upper secondary education 1940 (one year old) & $-.018 * * *$ & {$[.0050]$} & $-.012 * * *$ & [.0043] & $-.012 * * *$ & [.0039] \\
\hline 1941 (infant) & $-.022 * * *$ & {$[.0057]$} & $-.016 * *$ & [.0065] & $-.013 * *$ & [.0057] \\
\hline 1942 (fetus) & $-.023 * * *$ & {$[.0056]$} & -.006 & {$[.0075]$} & -.003 & [.0064] \\
\hline $\mathrm{N}$ & 123,793 & & 123,793 & & 123,793 & \\
\hline Years in education 1940 (one year old) & $-.149 * * *$ & {$[.0456]$} & $-.092 * *$ & [.0430] & $-.096 * *$ & [.0384] \\
\hline 1941 (infant) & $-.232 * * *$ & {$[.0522]$} & $-.172 * *$ & [.0653] & $-.146 * *$ & [.0558] \\
\hline 1942 (fetus) & $-.184 * * *$ & {$[.0502]$} & -.017 & [.0639] & .008 & [.0523] \\
\hline $\mathrm{N}$ & 123,793 & & 123,793 & & 123,793 & \\
\hline ISEI-score 1940 (one year old) & -.501 & [.3354] & -.282 & [.3289] & -.194 & [.3106] \\
\hline 1941 (infant) & $-.806 * *$ & {$[.3540]$} & -.563 & [.5257] & -.496 & [.4862] \\
\hline 1942 (fetus) & $-1.145^{* * *}$ & {$[.3275]$} & $-.493 *$ & {$[.2826]$} & -.292 & [2817] \\
\hline $\mathrm{N}$ & 42,285 & & 42,285 & & 42,285 & \\
\hline
\end{tabular}

All specifications use data from Greece-born individuals the 2001 census.

Column 1 shows results for our basic specification for Greece born individuals. Column 2 adds 53 prefecture of birth dummies to the regression in column 1 . Relative to the specification in Column 2, Column 3 adds an urban birthplace indicator and interactions of the 53 prefecture of birth dummies with this urban birthplace indicator. For Columns 2 and 3 we report robust standard errors clustered at the prefecture of birth level in brackets. 
birthplace effects, but also for prefecture specific consequences of being born in an urban area. For all models that include birthplace information we cluster standard errors at the prefecture level.

For the 1940 cohort of one year olds, we continue to find a statistically significant effect on literacy when including birthplace indicators in columns 2 and 3. In contrast, the estimate of the famine's impact on completing upper secondary or technical school drops from minus 1.8 percentage points in the basic specification in column 1 to minus 1.2 percentage points in columns 2 and 3. Similarly, the reduction in the number of years in education falls from 1.2 months to 0.8 about months after the inclusion of birthplace variables. The estimated impact on occupational prestige also falls in columns 2 and 3 and is no longer statistically significant.

For the 1941 cohort exposed during infancy we find a negative and statistically significant effect on literacy regardless whether or not we include birthplace controls. The estimated effects on upper secondary schooling and the number of years in education are smaller in columns 2 and 3 than in column 1, and remain statistically significant. Like for one year-olds the coefficients on job prestige falls for infants when including birthplace indicators and are no longer statistically significant.

In columns 2 and 3, the 1942 cohort exposed as fetuses has a lower chance of having completed upper secondary education and fewer years of education than those not exposed to the famine. However the point estimates are not statistically significant. Further, in column 3 fetal exposure is associated with a statistically significant half percentage point increase in the likelihood to be literate. Unlike in the basic specification, the reductions in the ISEI score for the 1942 cohort are small and not statistically significant in columns 2 and 3.

The reduction in the point estimates resulting from the inclusion of birthplace controls is consistent with the hypothesis that birthplaces associated with inferior outcomes in later 
life are overrepresented in the 1940-42 cohorts. The fact that the reductions are largest for fetuses is consistent with the hypothesis that this cohort experienced additional negative birthplace selection through fertility.

Because famine severity differed between urban and rural areas it is likely that the long-run effects on the 1940-42 cohorts are also different for urban and rural born cohorts. We account for this possibility by estimating separate models for the urban and rural born populations. By obtaining separate estimates of the 1940, 1941 and 1942 cohort effects for the urban and rural samples we are able to distinguish the long-run effects of severe famine exposure those of milder famine exposure.

For comparison purposes, Table 4 column 1 replicates the results for the entire 2001 sample of individuals born in Greece that we show in column 2 of Table 3. Column 2 has estimates for the 2001 sample of urban born Greeks and column 3 presents estimates for the 2001 sample of rural born Greeks.

For one year olds the estimates for literacy do not differ between the three Greeceborn subsamples in columns 1-3. In contrast, the chance of completing upper secondary school is 2.1 percentage points lower in the urban born cohort in column 2 as opposed to 0.8 percentage points in the rural born cohort in column 3. Years in education are 1.6 months lower for the urban born sample while we find only a small and statistically insignificant reduction for the rural born sample. In terms of occupational prestige we do not find statistically significant effects in the urban or rural samples.

For infants the small statistically significant reduction in the literacy rate for the full sample in column 1 is also present in the urban and rural subsamples in columns 2 and 3. Like for this 1940 cohort, the 3.3 percentage point reduction in upper secondary schooling and the 2.9 months reduction in years in education for the urban born cohort are multiple times larger than the statistically insignificant reductions for the rural born cohort. Like in the 
Table 4: OLS estimates of departures from 1936-46 cohort trend for different subsamples of the 2001 census

\begin{tabular}{|c|c|c|c|c|c|c|c|c|}
\hline \multirow[b]{2}{*}{ COHORT (exposed in) } & \multicolumn{2}{|c|}{$\begin{array}{c}\text { (1) Prefecture FE } \\
\text { Full Born Sample } 01\end{array}$} & \multicolumn{2}{|c|}{$\begin{array}{c}\text { (2) Prefecture FE } \\
\text { Urban Born Sample } 01\end{array}$} & \multicolumn{2}{|c|}{$\begin{array}{c}\text { (3) Prefecture FE } \\
\text { Rural Born Sample } 01\end{array}$} & \multicolumn{2}{|c|}{$\begin{array}{l}\text { (4) Country FE } \\
\text { Foreigner Born Sample } 01\end{array}$} \\
\hline & Coefficient & SE & Coefficient & SE & Coefficient & SE & Coefficient & $\mathrm{SE}$ \\
\hline Literate 1940 (one year old) & .000 & [.0019] & -.003 & [.0029] & .001 & [.0025] & -.006 & [.0115] \\
\hline 1941 (infant) & $-.007 * * *$ & [.0024] & $-.007 *$ & [.0040] & $-.006 * *$ & [.0031] & $-.016^{*}$ & [.0069] \\
\hline 1942 (fetus) & .004 & {$[.0024]$} & -.001 & {$[.0034]$} & $.005^{* *}$ & {$[.0027]$} & $-.018 * *$ & {$[.0105]$} \\
\hline $\mathrm{N}$ & 123,793 & & 40,053 & & 83,740 & & 5,811 & \\
\hline Upper secondary education 1940 (one year old) & $-.012 * * *$ & {$[.0043]$} & $-.021 * * *$ & {$[.0074]$} & $-.008 *$ & [.0042] & .021 & {$[.0208]$} \\
\hline 1941 (infant) & $-.016^{* *}$ & {$[.0065]$} & $-.033 * * *$ & [.0109] & -.004 & {$[.0054]$} & .013 & {$[.0269]$} \\
\hline 1942 (fetus) & -.006 & {$[.0075]$} & -.012 & [.0129] & .001 & [.0069] & -.010 & {$[.0258]$} \\
\hline $\mathrm{N}$ & 123,793 & & 40,053 & & 83,740 & & 5,811 & \\
\hline Years in education 1940 (one year old) & $-.092 * *$ & {$[.0430]$} & $-.188 * *$ & {$[.0779]$} & -.050 & [.0429] & .287 & {$[.2492]$} \\
\hline 1941 (infant) & $-.172 * *$ & {$[.0653]$} & $-.342 * * *$ & {$[.1006]$} & -.058 & {$[.0627]$} & .107 & [.1847] \\
\hline 1942 (fetus) & -.017 & [.0639] & -.034 & [.0956] & .027 & [.0642] & .056 & [.3056] \\
\hline $\mathrm{N}$ & 123,793 & & 40,053 & & 83,740 & & 5,811 & \\
\hline ISEI-score 1940 (one year old) & -.282 & [.3289] & -.159 & {$[.5290]$} & -.177 & [.3339] & -.378 & [1.123] \\
\hline 1941 (infant) & -.563 & [.5257] & -.962 & [.8925] & -.288 & [.5309] & -.807 & {$[.9800]$} \\
\hline 1942 (fetus) & $-.493 *$ & {$[.2826]$} & -.044 & [.5338] & -.377 & [.3616] & .802 & [1.217] \\
\hline $\mathrm{N}$ & 43,177 & & 12,859 & & 29,426 & & 2,229 & \\
\hline
\end{tabular}

In all specifications we use data from the 2001 census that contains birthplace information. In addition to the indicators for whether born in 1940, 1941, or 1942, all specifications include year of birth, year of birth squared and a sex indicator. In addition, specifications (1)-(3) include prefecture of birth dummies and specification (4) country of birth dummies. Column 1 reproduces Column 2 of Table 3. Column 3 estimates the specification in Column 2 for individuals born in urban areas and Column 3 does so for individuals burn on rural areas, Column 4 does for individuals born outside Greece. For Columns 1, 2 and 3 we report robust standard errors clustered at the prefecture of birth level in brackets. For Column 4, the robust standard errors reported in brackets are clustered at the country of birth level. 
majority of specifications, the adverse effects on upper secondary schooling and years in education are larger infants than for one year olds. We find no significant effect on job prestige in the urban and rural subsamples.

For fetuses we find a 0.5 percentage point statistically significant increase in the chance to be literate. The remaining estimates for the 1942 cohort are small in magnitude and not statistically significant.

The result that the adverse effects are largest for the urban born cohorts shows that exposure to more severe forms of famine leads to larger impairments of long-run outcomes. The lack of statistically significant effects for the rural born cohort is likely the result of low famine intensity in rural areas.

Because members of the 1940-42 foreign born cohorts are unlikely to have experienced systematic undernourishment early in life, we predict no significant departure in outcomes from the cohort trend for the foreign born cohorts. We test this hypothesis in Table 4, column 4 which does not include observations for Greece born individuals but a sample of foreign born individuals which is only available for the 2001 Census.

For the foreign-born subsample in column 4 we find significant reductions in literacy for those born in 1940 and 1941. We however do not find effects on upper secondary schooling, years in education and the ISEI score in any of the 1940-42 cohorts. The sum of the findings in column 4 is therefore consistent with our prediction in that foreign born individuals were not systematically negatively affected by the famine. That is unless they immigrated to Greece in their first two years of life. ${ }^{22}$ Our results for Greece-born individuals in Tables 2, 3 and 4 are thus unlikely to be a mere statistical anomaly.

\section{Conclusions}

\footnotetext{
${ }^{22}$ We obtain similar results for estimations based on the subsample of Albanian-born individuals that form the largest single group of immigrants in the 2001 census. Results are available from the authors on request.
} 
This paper is the first to examine the long run education and labor market effects from early life exposure to the Greek 1941-42 famine. In our baseline specification and across all four 1971, 1981, 1991 and 2001 census waves, we find statistically significant reductions in years in education and in the likelihood to complete upper secondary schooling. In addition, reductions in occupational prestige are statistically significant in the 1971, 1981 and 2001 censuses. The adverse long-run effects are typically larger for the cohorts exposed as infants, and fetuses, than for the cohort exposed as one year olds.

For the 2001 census that contains detailed birthplace information we eliminate the upward selection bias that is due to an overrepresentation of individuals born in areas with inferior educational opportunities in the 1940-42 cohorts. By controlling for birthplace we attempt to identify a lower bound of the true famine effect. In comparison to the baseline model, birthplace controls lower the education effects for the one year olds and infants by about one third but the effects remain statistically significant. By contrast, the effects on cohorts exposed as fetuses are very small and not statistically significant after the inclusion of birthplace controls. Rather than providing evidence against the fetal origins hypothesis, this finding may be driven by substantial positive selection in the 1942 cohort. Because the cohort was conceived in a situation of severe nutritional strain, positive selection in this cohort likely occurred not only through survival but in addition through fertility, that is during the famine fertility was lower for those at the lower distribution of income and skills than for those in the upper distribution.

Finally, contemporary sources suggest that the famine was more severe in urban than in rural areas. We exploit this cross-sectional variation by estimating separate models for the urban and rural born subsamples of the Greek 2001 census. In line with our prediction, the urban-born cohorts suffer larger negative impacts on educational outcomes than the ruralborn cohorts. For one-year olds and infants born in urban areas the likelihood to complete 
upper secondary school reduces by 2.1 and 3.3 percentage points, respectively. Years in education also reduce by 1.6 for the cohort exposed as one year olds and 2.9 months for that exposed during infancy.

Our results highlight the role of appropriate nutrition in the formation of human capital in particular in the first two years of life. They indicate that developmental lags in countries that frequently experience nutritional crisis may in part be due to lacking nutrition 


\section{References}

Allen, Lindsay. 1994. "Maternal micronutrient malnutrition: Effects on breast milk and infant nutrition, and priorities for intervention” SCN News, 11:21-27.

Almond Douglas and Bhashkar Mazumder. 2005. "The 1918 Influenza pandemic and subsequent health outcomes: an analysis of SIPP data” The American Economic Review, 95(2), Papers and Proceedings of the One Hundred Seventeenth Annual Meeting of the American Economic Association, Philadelphia, PA, January 7-9: 258-262.

Almond, Douglas, Kenneth Chay and David Lee. 2005. "The costs of low birthweight”. The Quarterly Journal of Economics, 120(3): 1031-83.\#

Almond, Douglas, Lena Edlund, Hongbin Li and Junsen Zhang. 2007. "Long-term effects of the 1959-61 China famine: mainland China and Hong Kong”. NBER Working Paper No. 13384.

Almond, Douglas. 2006. "Is the 1918 influenza pandemic over? Long-term effects of in utero influenza exposure in the post-1940 U.S. population.” Journal of Political Economy, 114(4): $672-711$.

Andersen. 2008. "Maternal and child undernutrition: effective action at the national level". Lancet, 371: 510-26.

Barker, David and Mark Hanson. 2004. "Altered regional blood flow in the fetus: the origins of cardiovascular disease?” Acta Paediatrica, 93:1559-1560.

Barker, David. 1998. "In utero programming of chronic disease”. Clinical Science, 95: 111128.

Behrman, Jere and Mark Rosenzweig. 2004. "Returns to Birthweight" The Review of Economics and Statistics, 86(2): 586-601.

Black, Sandra, Paul Devereux and Kjell Salvanes. 2007. "From the cradle to the labor market? The effect of birthweight on adult outcomes". The Quarterly Journal of Economics, 122(1): 409-39.

Brenner, Barry and G. Chartow. "1994. "Congenital oligonephropathy and the etiology of adult hypertension and progressive renal injury”. American Journal of Kidney Disfunctioning, 23(2):171-5.

Brown, Kenneth and Kathryn Dewey. 1992. "Relationships between maternal nutritional status and milk energy output of women in developing countries”. In: Mechanisms Regulating Lactation and Infant Nutrient Utilization (Mary Picciano and Bo Lönnerdal, eds.): 77-95. Wiley-Liss: New York.

Bryce, Jennifer, Denise Coitinho, Ian Danton-Hill, David Pelletier and Per Pinstrup-Andersen. 2008. "Maternal and child undernutrition: effective action at national level”. Lancet, 317: $510-26$

Case, Anne, Darren Lubotsky, and Christina Paxson. 2002. "Economic status and health in childhood: the origins of the gradient”. American Economic Review, 92(5):1308-1334.

Chen, Yuyu and Li-An Zhou. 2007. "The long-term health and economic consequences of the 1959-61 famine in China.” Journal of Health Economics, 26: 659-681.

Dewey, Kathryn. 1997. "Energy and protein requirements during lactation”. Annual Review of Nutrition, 17: 19-36. 
European Commission. 2009. "National summary sheets on education systems in Europe and ongoing reforms - Greece”. Accessed only 12-04-2009 at http://eacea.ec.europa.eu/education/eurydice/eurybase_en.php\#greece

Ganzeboom, Harry, Donald Treiman. 1996. "Internationally comparable measures of occupational status for the 1988 International Standard Classification of Occupations”. Social Science Research, 25: 201-239.

Ganzeboom, Harry, Paul De Graaf and Donald Treiman. 1992. “A standard international socio-economic index of occupational status”. Social Science Research 21: 1-56.

Gørgens, Tue, Xin Meng and Rhema Vaithianathan. 2007. "Stunting and selection effects of famine: a case study of the Great Chinese Famine". IZA Discussion Papers 2543.

Hales, Charles and David Barker (1992). “Type 2 (non-insulin-dependent diabetes mellitus: The thrifty phenotype hypothesis”. Diabetologica, 35: 595-601.

Hales, Charles. 1997. "Fetal and infant growth and impaired glucose tolerance in adulthood: The "thrifty phenotype” hypothesis revisited”. Acta Paediatrica, Suppl. 422: 73-77.

Helger, Bengt. 1949. “Ravitaillement de la Grèce pendant l'occupation 1941-44 et pendant les premiers cinq mois apres la libéraction”. Société Hellénique d’Éditions, Athens.

Hionidou, Violetta. 2006. "Famine and death in occupied Greece1941-44.” Cambridge University Press, Cambridge.

Hoddinott, John, John Maluccio, Jere Behrman, Rafael Flores and Reynaldo Martorell. 2008. "Effect of a nutrition intervention during early childhood on economic productivity in Guatemalan adults”. Lancet, 371: 411-16.

Hoet, Joseph and Mark Hanson.1999. "Intrauterine nutrition: its importance during critical periods for cardiovascular and endocrine development”. The Journal of Physiology, 514: 617627.

Jakobovits, Leon. 1991. "Sex ratio of spontaneously aborted fetuses and delivered neonates in the second trimester.” European Journal of Obstetrics and Gynecology and Reproductive Biology, 40: 211-213.

Kannisto, Väinö, Kaare Christensen and James Vaupel. 1997. "No increased mortality in later life for cohorts born during famine”. Epidemiology, 145(11): 987-994.

Luo, Zhehui, Ren Mu, and Xiaobo Zhang. 2006. “The Long Term Health Impact of the Chinese Great Famine”. Michigan State University Working Paper.

Mazower, Mark. 1993. “Inside Hitler's Greece. The Experience of Occupation 1941-44” Yale University Press, New Haven.

Meng, Xin and Nancy Qian. 2009. “The long-term consequences of famine on survivors: Evidence from a unique natural experiment using China’s Great Famine.” NBER Working Paper No. 14917.

Minnesota Population Center. 2009. Integrated Public Use Microdata Series, International: Version 5.0 [Machine-readable database]. Minneapolis: University of Minnesota. Online at https://international.ipums.org/international/citation.shtml

Neugebauer, Richard, Hans Hoek and Ezra Susser. 1999. "Prenatal exposure to wartime famine and development of antisocial personality disorder in early adulthood”. JAMA, 282(5): 455-462. 
Oreopoulos, Philip Mark Stabile, Randy Walld and Leslie Roos. 2008. "Short-, medium, and long-term consequences of poor infant health: an analysis using siblings and twins". Journal of Human Resources, 43(1): 88-138.

Rasmussen, Kathleen. 2001. "The "fetal origins” hypothesis: challenges and opportunities for maternal and child nutrition”. Annual Review of Nutrition, 21: 73-95.

Ravelli, Anita, Jan van der Meulen, Clive Osmond, David Barker, and Otto Bleker. 1999. "Obesity at the age of 50 in men and women exposed to famine prenatally." American Journal of Clinical Nutrition, 70: 811-816.

Ravelli, Anita, Jan van der Meulen, Clive Osmond, David Barker, Charles Hales, and Otto Bleker. 1998. “Glucose tolerance in adults after prenatal exposure to famine”. Lancet, 351: 173-177.

Roseboom, Tessa, Jan van der Meulen, Anita Ravelli, Clive Osmond, David Barker and Otto Bleker. 2001. "Effects of prenatal exposure to the Dutch famine on adult disease in later life: an overview." Molecular and Cellular Endocrinology, 185: 93-98.

Roseboom, Tessa, Jan van der Meulen, Anita Ravelli, Gert van Montfrans, Clive Osmond, David Barker and Otto Bleker. 1999. "Blood pressure in adults after prenatal exposure to famine”. Journal of Hypertension, 17: 325-330.

Roseboom, Tessa, Jan van der Meulen, Clive Osmond, David Barker, Anita Ravelli and Otto Bleker. 2000a. "Plasma lipid profiles in adults after prenatal exposure to the Dutch famine". American Journal of Clinical Nutrition, 72: 1101-1106.

Roseboom, Tessa, Jan van der Meulen, Clive Osmond, David Barker, Anita Ravelli, Jutta Schroeder-Tanka, Gert van Montfrans, Robert Michels and David Barker. 2000b. "Coronary heart disease after prenatal exposure to the Dutch famine 1944-45”. Heart, 84: 595-598.

Song, Shige. 2009. "Does famine have a long-term effect on cohort mortality? Evidence from the 1959-61 Great Leap Forward Famine in China”. Journal of Biosocial Science, 41: 469491.

St Clair, David, Mingqing Xu, Peng Wang, Yaqin Yu, Yourong Fang, Feng Zhang, Xiaoying Zheng, Niufan Gu, Guoyin Feng, Pak Sham and Lin He. 2005. "Rates of adult schizophrenia following prenatal exposure to the Chinese Famine of 1959-1961". JAMA, 294: 557-562.

Stanner, S. and J. Yudkin. 2001. "Fetal programming and the Leningrad Siege Study”. Twin Research, 4(5): 287-92.

Stanner, S., K. Bulmer, C. Andres, O. Lantseva, V. Borodina, V. Poteen, and J. Yudkin. 1997. "Does malnutrition in utero determine diabetes and coronary heart disease in adulthood? Results from the Leningrad Siege Study, a cross sectional-study.” British Medical Journal, 315: 1342-48.

Stocker, Claire, J. Arch and M. Cawthorne. 2005. "Fetal origins of insulin resistance and obesity”. The Proceedings of the Nutrition Society, 64(2):143-51.

Valaoras, Vasilios. 1946. "Some effects of famine on the population of Greece”. The Milbank Memorial Fund Quarterly, 24(3): 215-234.

Valaoras, Vasilios. 1960. "A reconstruction of the demographic history of modern Greece”. The Milbank Memorial Fund Quarterly, 38(2): 115-139.

Victoria, Cesar, Linda Adair, Caroline Fall, Pedro Hallal, Reynaldo Martorell, Linda Richter and Harshpal Singh Sachdev. 2008. "Maternal an child undernutrition: consequences for adult health and human capital”. Lancet, 371: 340-57. 
Walker, Susan, Theodore Wachs, Julie Meeks Gardner, Betsy Lozoff, Gail Wasserman, Ernesto Pollitt and Julie Carter. 2007. "Child development: risk factors for adverse outcomes in developing countries”. Lancet, 369: 145-57.

World Health Organization. 2009. "Infant and young child feeding - model chapter for textbooks for medical students and allied health professionals". Accessed online 02-12-2010 at http://whqlibdoc.who.int/publications/2009/9789241597494_eng.pdf

Yao, Shujie. 1999. “A note on the causal factors of China's Famine 1959-61”. Journal of Political Economy, 107(6), pt 1: 1365-69. 


\section{CESifo Working Paper Series}

for full list see www.cesifo-group.org/wp

(address: Poschingerstr. 5, 81679 Munich, Germany, office@cesifo.de)

2929 J. Trent Alexander, Michael Davern and Betsey Stevenson, Inaccurate Age and Sex Data in the Census PUMS Files: Evidence and Implications, January 2010

2930 Stefan Krasa and Mattias K. Polborn, Competition between Specialized Candidates, January 2010

2931 Yin-Wong Cheung and Xingwang Qian, Capital Flight: China's Experience, January 2010

2932 Thomas Hemmelgarn and Gaetan Nicodeme, The 2008 Financial Crisis and Taxation Policy, January 2010

2933 Marco Faravelli, Oliver Kirchkamp and Helmut Rainer, Social Welfare versus Inequality Concerns in an Incomplete Contract Experiment, January 2010

2934 Mohamed El Hedi Arouri and Christophe Rault, Oil Prices and Stock Markets: What Drives what in the Gulf Corporation Council Countries?, January 2010

2935 Wolfgang Lechthaler, Christian Merkl and Dennis J. Snower, Monetary Persistence and the Labor Market: A New Perspective, January 2010

2936 Klaus Abberger and Wolfgang Nierhaus, Markov-Switching and the Ifo Business Climate: The Ifo Business Cycle Traffic Lights, January 2010

2937 Mark Armstrong and Steffen Huck, Behavioral Economics as Applied to Firms: A Primer, February 2010

2938 Guglielmo Maria Caporale and Alessandro Girardi, Price Formation on the EuroMTS Platform, February 2010

2939 Hans Gersbach, Democratic Provision of Divisible Public Goods, February 2010

2940 Adam Isen and Betsey Stevenson, Women's Education and Family Behavior: Trends in Marriage, Divorce and Fertility, February 2010

2941 Peter Debaere, Holger Görg and Horst Raff, Greasing the Wheels of International Commerce: How Services Facilitate Firms' International Sourcing, February 2010

2942 Emanuele Forlani, Competition in the Service Sector and the Performances of Manufacturing Firms: Does Liberalization Matter?, February 2010

2943 James M. Malcomson, Do Managers with Limited Liability Take More Risky Decisions? An Information Acquisition Model, February 2010 
2944 Florian Englmaier and Steve Leider, Gift Exchange in the Lab - It is not (only) how much you give ..., February 2010

2945 Andrea Bassanini and Giorgio Brunello, Barriers to Entry, Deregulation and Workplace Training: A Theoretical Model with Evidence from Europe, February 2010

2946 Jan-Emmanuel De Neve, James H. Fowler and Bruno S. Frey, Genes, Economics, and Happiness, February 2010

2947 Camille Cornand and Frank Heinemann, Measuring Agents' Reaction to Private and Public Information in Games with Strategic Complementarities, February 2010

2948 Roel Beetsma and Massimo Giuliodori, Discretionary Fiscal Policy: Review and Estimates for the EU, February 2010

2949 Agnieszka Markiewicz, Monetary Policy, Model Uncertainty and Exchange Rate Volatility, February 2010

2950 Hans Dewachter and Leonardo Iania, An Extended Macro-Finance Model with Financial Factors, February 2010

2951 Helmuth Cremer, Philippe De Donder and Pierre Pestieau, Education and Social Mobility, February 2010

2952 Zuzana Brixiová and Balázs Égert, Modeling Institutions, Start-Ups and Productivity during Transition, February 2010

2953 Roland Strausz, The Political Economy of Regulatory Risk, February 2010

2954 Sanjay Jain, Sumon Majumdar and Sharun W. Mukand, Workers without Borders? Culture, Migration and the Political Limits to Globalization, February 2010

2955 Andreas Irmen, Steady-State Growth and the Elasticity of Substitution, February 2010

2956 Bengt-Arne Wickström, The Optimal Babel - An Economic Framework for the Analysis of Dynamic Language Rights, February 2010

2957 Stefan Bauernschuster and Helmut Rainer, From Politics to the Family: How Sex-Role Attitudes Keep on Diverging in Reunified Germany, February 2010

2958 Patricia Funk and Christina Gathmann, How do Electoral Systems Affect Fiscal Policy? Evidence from State and Local Governments, 1890 to 2005, February 2010

2959 Betsey Stevenson, Beyond the Classroom: Using Title IX to Measure the Return to High School Sports, February 2010

2960 R. Quentin Grafton, Tom Kompas and Ngo Van Long, Biofuels Subsidies and the Green Paradox, February 2010 
2961 Oliver Falck, Stephan Heblich, Alfred Lameli and Jens Suedekum, Dialects, Cultural Identity, and Economic Exchange, February 2010

2962 Bård Harstad, The Dynamics of Climate Agreements, February 2010

2963 Frederick van der Ploeg and Cees Withagen, Is There Really a Green Paradox?, February 2010

2964 Ingo Vogelsang, Incentive Regulation, Investments and Technological Change, February 2010

2965 Jan C. van Ours and Lenny Stoeldraijer, Age, Wage and Productivity, February 2010

2966 Michael Hoel, Climate Change and Carbon Tax Expectations, February 2010

2967 Tommaso Nannicini and Roberto Ricciuti, Autocratic Transitions and Growth, February 2010

2968 Sebastian Brauer and Frank Westermann, A Note on the Time Series Measure of Conservatism, February 2010

2969 Wolfram F. Richter, Efficient Education Policy - A Second-Order Elasticity Rule, February 2010

2970 Tomer Blumkin, Yoram Margalioth and Efraim Sadka, Taxing Children: The Redistributive Role of Child Benefits - Revisited, February 2010

2971 Chang Woon Nam and Georg Wamser, Application of Regionally Varying Additionality Degrees in the Practice of EU Cohesion Policy, February 2010

2972 Ali Bayar, Frédéric Dramais, Cristina Mohora, Masudi Opese and Bram Smeets, Modeling Russia for Climate Change Issues, February 2010

2973 Magnus Söderberg, Informal Benchmarks as a Source of Regulatory Threat in Unregulated Utility Sectors, March 2010

2974 Piotr Wdowiński and Marta Malecka, Asymmetry in Volatility: A Comparison of Developed and Transition Stock Markets, March 2010

2975 Frans van Winden, Michal Krawczyk and Astrid Hopfensitz, Investment, Resolution of Risk, and the Role of Affect, March 2010

2976 Hyun-Ju Koh and Nadine Riedel, Do Governments Tax Agglomeration Rents?, March 2010

2977 Johann K. Brunner and Susanne Pech, Optimum Taxation of Bequests in a Model with Initial Wealth, March 2010

2978 Guglielmo Maria Caporale and Nicola Spagnolo, Stock Market Integration between three CEECs, Russia and the UK, March 2010 
2979 Florian Englmaier, Ales Filipi and Ravi Singh, Incentives, Reputation and the Allocation of Authority, March 2010

2980 Konstantinos Angelopoulos, George Economides and Apostolis Philippopoulos, What is the Best Environmental Policy? Taxes, Permits and Rules under Economic and Environmental Uncertainty, March 2010

2981 Frederick van der Ploeg, Rapacious Resource Depletion, Excessive Investment and Insecure Property Rights, March 2010

2982 Wolfram F. Richter and Christoph Braun, Efficient Subsidization of Human Capital Accumulation with Overlapping Generations and Endogenous Growth, March 2010

2983 Francesco Cinnirella, Marc Piopiunik and Joachim Winter, Why Does Height Matter for Educational Attainment? Evidence from German Pre-Teen Children, March 2010

2984 Bernard Van Praag, Well-being Inequality and Reference Groups - An Agenda for New Research, March 2010

2985 Francesca Barion, Raffaele Miniaci, Paolo M. Panteghini and Maria Laura Parisi, Profit Shifting by Debt Financing in Europe, March 2010

2986 Alexander Haupt and Magdalena Stadejek, The Choice of Environmental Policy Instruments: Energy Efficiency and Redistribution, March 2010

2987 John Komlos and Marek Brabec, The Trend of BMI Values among US Adults, March 2010

2988 Emanuele Massetti and Lea Nicita, The Optimal Climate Policy Portfolio when Knowledge Spills across Sectors, March 2010

2989 Helmut Rainer and Thomas Siedler, Family Location and Caregiving Patterns from an International Perspective, March 2010

2990 Toru Kikuchi and Ngo Van Long, A Simple Model of Service Offshoring with Time Zone Differences, March 2010

2991 Assaf Razin, Efraim Sadka and Benjarong Suwankiri, Migration and the Welfare State: Dynamic Political-Economy Theory, March 2010

2992 Bård Harstad, Buy Coal! Deposit Markets Prevent Carbon Leakage, March 2010

2993 Axel Dreher, Stephan Klasen, James Raymond Vreeland and Eric Werker, The Costs of Favoritism: Is Politically-driven Aid less Effective?, March 2010

2994 Sven Neelsen and Thomas Stratmann, Effects of Prenatal and Early Life Malnutrition: Evidence from the Greek Famine, March 2010 